\title{
Meningkatkan hasil belajar dan kemandirian belajar peserta didik dengan menggunakan Android Studio (Increasing student's learning result and self-regulated learning by using Android Studio)
}

\author{
Livia Dinda Rochmawati, Madziatul Chuuriyah* \\ Universitas Negeri Malang, Jl. Semarang No. 5 Malang, Jawa Timur, Indonesia \\ *Penulis korespondensi, Surel: madziatul.chuuriyah.fe@um.ac.id
}

Paper received: 7-6-2021; revised: 21-6-2021; accepted: 28-6-2021

\begin{abstract}
Abstrak
Penggunaan media dalam kegiatan pembelajaran dapat membantu keterbatasan yang dimiliki guru/pendidik dalam menyampaikan materi yang ingin diajarkan, terutama untuk pelaksanaan kegiatan pembelajaran secara daring dari jarak jauh seperti saat ini. Salah satu sekolah yang menerapkan hal tersebut adalah SMK Negeri 1 Turen Kabupaten Malang. Tujuan dari penelitian ini untuk mengembangkan media pembelajaran berbasis Android Studio, mengetahui kelayakan media pembelajaran berbasis Android Studio, mengetahui perbedaan hasil belajar peserta didik, dan mengetahui perbedaan self regulated learning peserta didik pada mata pelajaran Korespondensi Bahasa Indonesia untuk kelas X yang mampu meningkatkan hasil belajar dan kemandirian belajar peserta didik. Metode penelitian dan pengembangan yang digunakan adalah Research and Development yang dicetuskan oleh Sugiyono dan terdiri dari 9 langkah, diantaranya adalah potensi dan masalah, pengumpulan data, desain produk, validasi desain, revisi desain, uji coba produk, revisi produk, uji coba pemakaian, dan produksi massal. Hasil akhir dari penelitian ini adalah meningkatnya hasil belajar dan kemandirian peserta didik dari kelas eksperimen dibandingkan dengan kelas kontrol.
\end{abstract}

Kata kunci: Android Studio; Student's Learning Result; Self-Regulated Learning; Learning Media; Learning Media Usage

\section{Pendahuluan}

Pendidikan sudah menjadi suatu kebutuhan mendasar bagi setiap manusia yang juga memiliki peranan penting bagi kehidupan yang lebih baik dan berkualitas. Hal ini dapat diartikan bahwa pendidikan merupakan salah satu aspek penting dalam kehidupan yang dapat memberikan kontribusi sangat besar dalam kemajuan suatu bangsa. Namun pada era pandemi Covid-19 seperti yang sedang terjadi saat ini, pemerintah mengeluarkan Surat Edaran Kemendikbud No. 4 Tahun 2020 mengenai Pelaksanaan Pendidikan Dalam Masa Darurat Covid-19. Seiring berkembangnya zaman, pendidikan telah mengalami perubahan yang sangat pesat. Dimana teknologi dan informasi digital mulai berkembang sehingga penyelenggaraan pembelajaran mulai tergeser dari pembelajaran konvensional menuju pembelajaran yang lebih modern. Dari perkembangan teknologi tersebut, maka dapat membantu tenaga pendidikan dalam menciptakan suatu media pembelajaran.

Media pembelajaran merupakan suatu alat atau bahan yang digunakan sebagai perantara komunikasi dalam kegiatan pembelajaran penggunaan media sebagai bahan ajar harus bervariasi agar dalam proses pembelajaran, peserta didik tidak merasa jenuh dan proses pembelajaran tidak akan terganggu akibat kecenderungan peserta didik yang tidak memperhatikan guru, khususnya pada pembelajaran secara daring. Peranan media dalam 
kegiatan pembelajaran merupakan bagian yang sangat menentukan efektivitas dan efisiensi pencapaian tujuan pembelajaran (Setyosari, 2005:17). Terdapat bermacam-macam media pembelajaran yang dapat dimanfaatkan dalam pembelajaran , diantaranya ada media berbasis cetak, berbasis visual, berbasis audio visual, dan berbasis komputer. Keragaman jenis media pembelajaran tersebut dapat digunakan untuk menunjang pembelajaran (Arsyad, 2003). Gagne \& Briggs dalam (Arsyad, 2003) secara implisit mengatakan bahwa media pembelajaran meliputi alat yang secara fisik digunakan untuk menyampaikan isi materi pengajaran, yang terdiri dari buku, tape recorder, kaset, video kamera, video recorder, film, slide, foto, gambar, grafik, televisi, dan komputer. Dengan kata lain, dapat dikatakan bahwa media merupakan komponen sumber belajar atau wahana fisik yang mengandung materi instruksional di lingkungan peserta didik untuk belajar.

Pada era ini, penggunaan media pembelajaran berbasis Android sangat efektif untuk digunakan. Salah satu contoh aplikasi untuk membuat media pembelajaran berbasis Android adalah Android Studio, yang merupakan salah satu implementasi dari IDE (Integrated Development Environment). IDE merupakan sebuah lingkungan pengembangan yang terintegrasi resmi yang dirancang untuk pengembangan sistem operasi Google Android (Firly, 2018). Dengan kata lain Android Studio adalah sebuah IDE atau sebuah perangkat lunak yang digunakan untuk membangun aplikasi yang berjalan pada platform android. Penerapan media pembelajaran berbasis Android Studio dalam mata pelajaran Korespondensi pada penelitian ini ditujukan untuk meningkatkan hasil belajar dan self regulated learning peserta didik. Hasil belajar peserta didik pada hakikatnya merupakan perubahan tingkah laku yang diinginkan pada diri peserta didik. Tingkah laku yang dimaksud adalah tingkah laku sebagai hasil belajar dalam pengertian yang luas mencakup bidang kognitif, afektif dan psikomotorik. Self Regulated Learning peserta didik sangat diperlukan agar peserta didik mempunyai tanggung jawab dalam mengatur dan mendisiplinkan dirinya, serta mengembangkan kemampuan belajar atas kemauannya sendiri. Peserta didik dikatakan mandiri apabila mampu melakukan tugas belajar tanpa mempunyai ketergantungan kepada orang lain, mampu mengatasi permasalahan sendiri, mempunyai rasa percaya diri dan tanggung jawab (Nurhayati, 2011).

Beberapa penelitian sebelumnya yang turut membahas topik serupa dengan penelitian ini adalah penelitian yang dilakukan oleh Liliarti dan Kuswanto (2018); Ana and Achdiani (2015); Bartholomew, dkk (2017); Mukti and Nurcahyo (2017); Wahyuni dan Djukri (2016); Taufiq, dkk (2016); Kusumadewi (2016); Kularbphettong, dkk (2015); Astra, dkk (2015); dan Lubis dan Ikhsan (2015). Berdasarkan hasil dari penelitian-penelitian tersebut, dapat diketahui bahwa penggunaan media pembelajaran berbasis Android mampu meningkatkan hasil belajar dan kemandirian belajar peserta didik dalam berlangsungnya kegiatan belajar mengajar.

Berdasarkan hasil observasi yang dilakukan oleh peneliti di SMK Negeri 1 Turen, Kabupaten Malang, peneliti memperoleh informasi bahwa pada saat proses pembelajaran mata pelajaran korespondensi, dirasa sedikit sulit untuk memaparkan materi kepada peserta didik, dikarenakan terdapat beberapa kendala atau permasalahan yang ditemukan. Diantaranya terdapat gangguan internet atau gangguan jaringan yang dimiliki peserta didik ataupun guru, terlebih lagi ada peserta didik yang rumahnya kurang dari akses jaringan atau internet. Pada pembelajaran daring (online) seperti ini peserta didik lebih sering memakai smartphone untuk melakukan pembelajaran, serta media elektronik yang selalu dekat dengan peserta didik adalah smartphone. Maka dari itu, peneliti akan memanfaatkan teknologi yang 
akan dikembangkan ke dalam media pembelajaran yang friendly dengan berbasis android yang dapat memudahkan peserta didik dalam proses pembelajaran, terutama pada peserta didik kelas X Otomatisasi Tata Kelola Perkantoran, khususnya pada mata pelajaran Korespondensi dengan Kompetensi Dasar Surat Elektronik. Peneliti akan membuat tampilan media pembelajaran berbasis android semenarik mungkin guna menarik perhatian peserta didik agar peserta didik tidak merasa monoton dan akan lebih tertarik. Sebelum produk atau media pembelajaran berbasis android ini diproduksi atau dipublikasikan, peneliti akan melakukan validasi terlebih dahulu agar media yang digunakan sudah pasti layak untuk diterapkan dalam proses pembelajaran daring maupun luring nantinya.

\section{Metode}

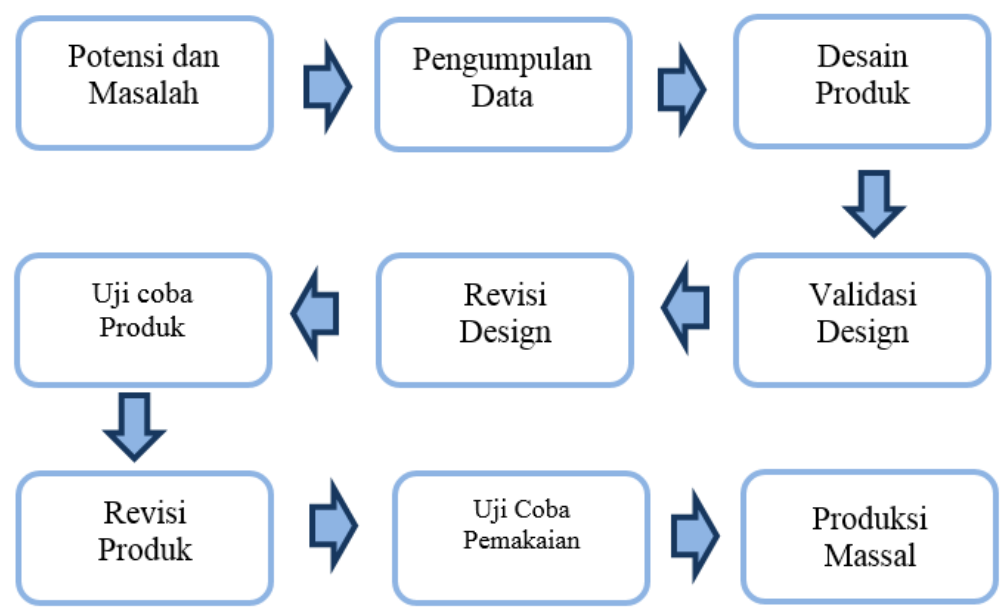

Gambar 1. Langkah-Langkah Penelitian dan Pengembangan

Metode penelitian yang digunakan dalam penelitian ini adalah metode Research and Development yang dicetuskan oleh Borg and Gall. Langkah penelitian tersebut terdiri dari sepuluh rangkaian langkah penelitian yang saling berhubungan. Namun dalam penelitian ini, peneliti melakukan modifikasi langkah yang dikarenakan oleh keterbatasan peneliti dalam melakukan penelitian dan menimbang efektivitas penelitian. Sehingga peneliti memodifikasi sepuluh langkah tersebut menjadi sembilan langkah penelitian seperti yang tersaji dalam Gambar 1.

Langkah pertama, peneliti akan melakukan potensi masalah dengan melakukan observasi guna untuk mengetahui informasi mengenai kondisi riil yang terjadi pada saat proses pembelajaran di SMKN 1 Turen Kabupaten Malang. Langkah kedua, peneliti akan mengumpulkan data dari guru maupun peserta didik di SMK Negeri 1 Turen Kabupaten Malang berupa kuesioner serta hasil wawancara mengenai bahan yang dibutuhkan dalam pengembangan media pembelajaran berbasis Android Studio. Langkah ketiga, peneliti akan melakukan desain produk dengan mengembangkan media pembelajaran berbasis Android Studio. Langkah keempat, peneliti akan melakukan validasi desain yang dibantu oleh validator ahli media dan ahli materi untuk mengetahui kelayakan media yang dikembangkan. Langkah kelima, peneliti akan melakukan revisi desain yang berdasar pada kritik dan saran yang didapatkan dari validator. Langkah keenam, peneliti akan melakukan uji coba produk pada kelompok kecil yang subjeknya merupakan 6 peserta didik terpilih sesuai dengan tingkatan 
kemampuan akademiknya. Langkah ketujuh, peneliti akan melakukan revisi produk yang berdasar pada kritik dan saran yang diberikan oleh 6 peserta didik pada uji coba kelompok kecil. Langkah kedelapan, peneliti akan melakukan uji coba pemakaian pada peserta didik yang terdiri dari kelas eksperimen dan kelas kontrol. Langkah kesembilan, peneliti akan melakukan revisi produk yang berdasarkan pada pertimbangan uji coba pemakaian pada peserta didik.

Adapun data yang dihasilkan dari penelitian ini berupa data kualitatif dan data kuantitatif. Data kualitatif dalam penelitian ini didapatkan dari kritik dan saran yang diberikan pada validator ahli media dan ahli materi, serta subjek penelitian. Sedangkan data kuantitatif didapatkan dari skor pada angket validasi maupun angket yang diisi oleh subjek penelitian. Data kuantitatif ini kemudian akan diolah dengan memanfaatkan bantuan aplikasi Statistical Package for Social Sciences (SPSS) dengan menggunakan uji Independent Sample T-test untuk mengetahui perbedaan hasil belajar peserta didik antara kelas eksperimen dan kelas kontrol. Sementara untuk mengetahui perbedaan tingkat kemandirian belajar peserta didik, peneliti melakukan penghitungan dengan menggunakan rumus yang sudah ditentukan.

\section{Hasil dan Pembahasan}

Produk yang dihasilkan dalam penelitian dan pengembangan ini adalah media pembelajaran berbasis Android Studio untuk mata pelajaran Korespondensi KD 3.8 dan KD 3.9 pada kelas X di SMKN 1 Turen Kabupaten Malang. Tampilan awal dari media pembelajaran berbasis Android Studio yang dikembangkan dapat dilihat pada Gambar 2 berikut ini.

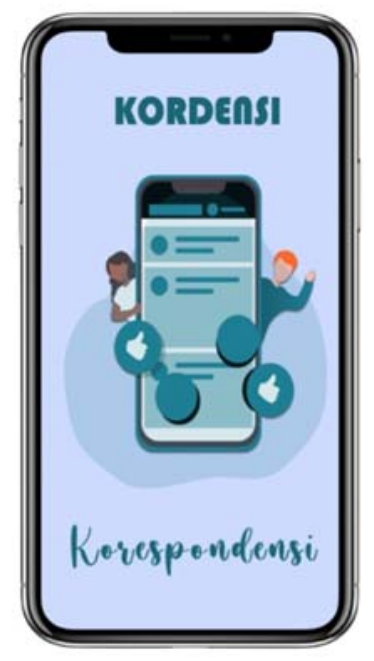

Gambar 2. Halaman Opening

Setelah halaman tersebut terlihat, selanjutnya pengguna media akan ditujukan pada halaman mulai yang dapat dilihat pada Gambar 3 di bawah ini. 


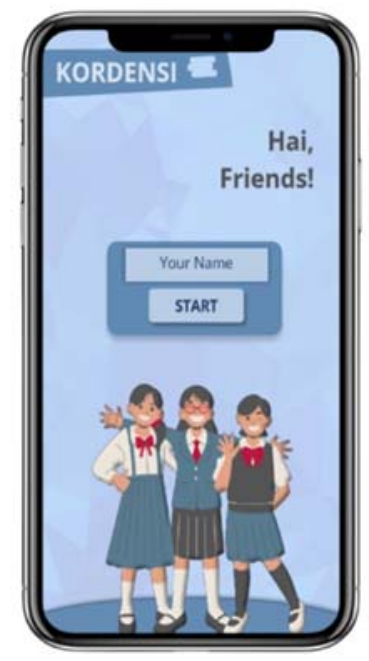

Gambar 3. Halaman Mulai

Apabila pengguna telah melalui tahap login pada halaman mulai, selanjutnya pengguna akan langsung diarahkan pada halaman menu utama yang berisi fitur dan pilihan menu yang disediakan oleh peneliti dalam media pembelajaran yang dikembangkan. Selengkapnya dapat disajikan dalam Gambar 4 berikut.

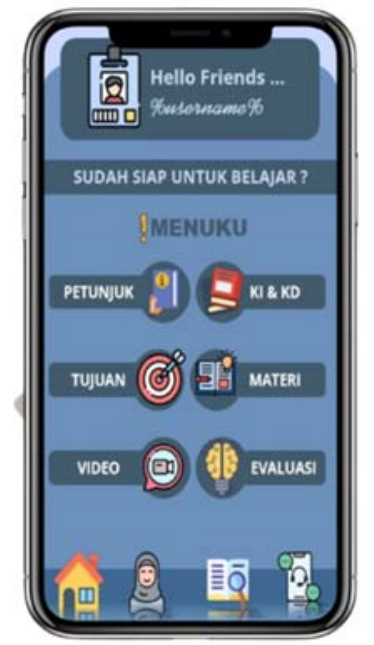

Gambar 4. Halaman Menu Utama

Hasil validasi dari produk media pembelajaran berbasis Android Studio yang dikembangkan oleh validator ahli media, validator ahli materi, dan enam peserta didik pada uji coba kelompok kecil secara keseluruhan disajikan dalam Tabel 1 sebagai berikut. 
Tabel 1. Persentase Keseluruhan Data Hasil Validasi

\begin{tabular}{llll}
\hline No. & \multicolumn{1}{c}{ Validasi } & Presentase & \multicolumn{1}{c}{ Kriteria Validitas } \\
\hline 1. & Ahli Media & $97,64 \%$ & Sangat Valid \\
2. & Ahli Materi & $91,25 \%$ & Sangat Valid \\
3. & Uji Coba Kelompok Kecil (6 Peserta & $94,25 \%$ & Sangat Valid \\
$\quad$ Didik) & $94,38 \%$ & Sangat Valid \\
\hline
\end{tabular}

Table is used with permission @Rochmawati, Livia Dinda. 2021. Persentase keseluruhan data hasil validasi.

Berdasarkan penjelasan pada Tabel 1 tersebut di atas, dapat diketahui bahwa hasil ratarata persentase validasi secara keseluruhan sebesar 94,38\%, sehingga peneliti dapat menyimpulkan bahwa penggunaan media pembelajaran berbasis Android Studio yang dikembangkan oleh peneliti dinyatakan "Sangat Valid" dan sangat layak untuk digunakan dalam kegiatan pembelajaran pada mata pelajaran Korespondensi kelas X KD 3.8 dan KD 3.9 di SMK Negeri 1 Turen Kabupaten Malang.

Media pembelajaran yang dikembangkan oleh peneliti memungkinkan peserta didik untuk dapat mengaksesnya melalui ponsel pribadi berbasis android. Dalam hal ini, Android Studio merupakan sebuah sistem IDE (Integrated Development Environment) yang merupakan sebuah lingkungan pengembangan yang terintegrasi resmi yang dirancang untuk pengembangan sistem operasi Google Android (Firly, 2018). Peneliti mendesain media pembelajaran yang dikembangkan sedemikian rupa dengan tambahan beberapa ilustrasi media guna untuk meningkatkan kualitas belajar peserta didik khususnya pada aspek hasil belajar dan kemandirian belajar. Tampilan dari halaman yang menunjukkan ilustrasi media tersebut dapat dilihat pada Gambar 5 sebagai berikut.

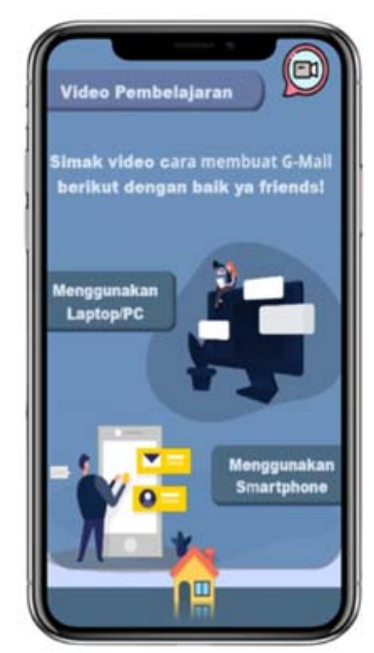

Gambar 5. Menu Video Pembelajaran

Perbedaan hasil belajar peserta didik antara kelas eksperimen dan kelas kontrol akan disajikan dalam Tabel 2 sebagai berikut, dimana data tersebut diolah dengan memanfaatkan bantuan aplikasi SPSS dan menggunakan metode uji Independent Sample T-test. 
Tabel 2. Hasil Uji Independent Sample T-test

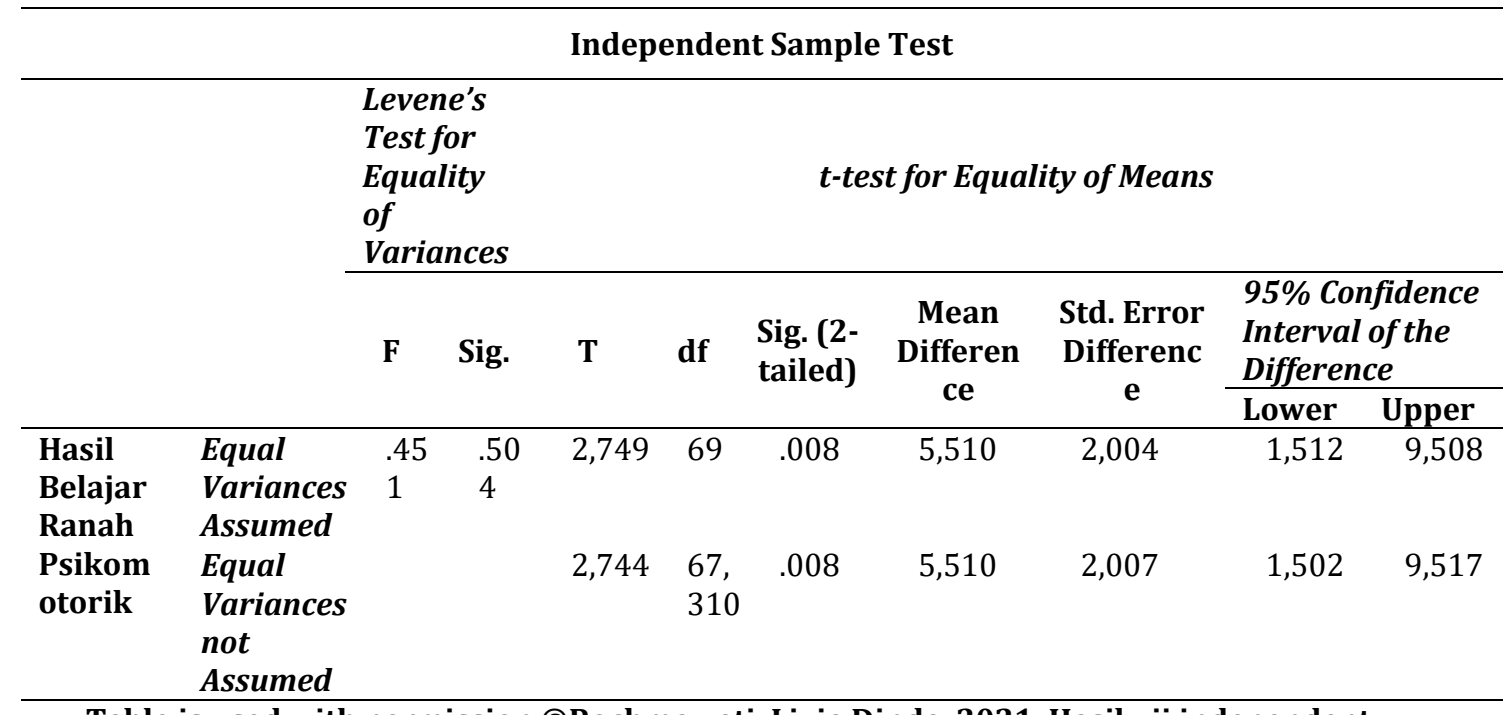

Table is used with permission (CRochmawati, Livia Dinda. 2021. Hasil uji independent sample T-test.

Berdasarkan Tabel 2 di atas, dapat diketahui bahwa pada baris Equal variances assumed terdapat kolom Sig. (2-tailed) yang menunjukkan angka sebesar 0,008<0,05. Sehingga dengan demikian, dapat ditarik kesimpulan bahwa dasar dalam pengambilan keputusan pada uji Independent Sample T-test adalah $\mathrm{H}_{\mathrm{o}}$ ditolak dan $\mathrm{H}_{\mathrm{a}}$ diterima. Maka dari itu, dapat disimpulkan bahwa terdapat perbedaan yang signifikan pada hasil belajar peserta didik pada ranah psikomotorik yang diperoleh dari hasil post test pada kelas eksperimen dan kelas kontrol. Untuk menunjukkan perbedaan dari hasil rata-rata nilai post test pada kelas eksperimen dan kelas kontrol, peneliti menyajikan datanya dalam Tabel 3 sebagai berikut.

Tabel 3. Hasil Deskriptif Statistik Hasil Belajar Ranah Psikomotorik

\begin{tabular}{lllllll}
\hline & \multicolumn{7}{c}{ Descriptive Statistics } \\
\hline & Kelas & N & Minimum & Maximum & Mean & $\begin{array}{l}\text { Std. } \\
\text { Deviation }\end{array}$ \\
\hline $\begin{array}{l}\text { Hasil Belajar } \\
\text { Ranah } \\
\text { Psikomotorik }\end{array}$ & Konsperimen & 36 & 70 & 98 & 81,14 & 7,882 \\
\hline
\end{tabular}

Table is used with permission (CRochmawati, Livia Dinda. 2021. Hasil deskriptif statistik hasil belajar ranah psikomotorik.

Berdasarkan Tabel 3 diatas, maka dapat dilihat perbedaan hasil belajar ranah psikomotorik peserta didik dari hasil nilai posttest kelas eksperimen dan kelas kontrol. Nilai rata-rata hasil belajar yang diperoleh kelas eksperimen adalah sebesar 81,14 sedangkan nilai rata-rata dari hasil belajar kelas kontrol sebesar 75,63 sehingga dari hasil deskriptif statistic dapat diartikan bahwa terdapat perbedaan rata-rata hasil belajar ranah psikomotorik peserta didik antara kelas eksperimen dan kelas kontrol.

Sementara untuk mengetahui perbedaan tingkat kemandirian belajar peserta didik, peneliti memberikan angket/kuesioner dengan instrumen pertanyaan yang serupa antara kelas eksperimen dan kelas kontrol. Setelah subjek penelitian mengisi setiap instrumen 
pertanyaan pada angket yang diberikan, peneliti melakukan penghitungan skor angket dengan menggunakan rumus yang telah ditentukan terlebih dahulu. Hasil keseluruhan persentase pada masing-masing instrumen pertanyaan pada kelas eksperimen dan kelas kontrol disajikan dalam Tabel 4 sebagai berikut.

Tabel 4. Persentase Setiap Aspek Self-Regulated Learning

\begin{tabular}{lcc}
\hline \multicolumn{1}{c}{ Aspek } & \multicolumn{2}{c}{ Persentase } \\
\cline { 2 - 3 } & Kelas Eksperimen & Kelas Kontrol \\
\hline Evaluasi Diri & 82 & 77 \\
Mengatur dan Mengubah & 80 & 72 \\
Menetapkan tujuan dan perencanaan & 77 & 77 \\
Mencari Informasi & 88 & 86 \\
Menyimpan Catatan dan Memantau & 78 & 72 \\
Konsekuensi Diri & 81 & 81 \\
Mengulang dan Mengingat & 75 & 69 \\
Mencari dukungan Sosial & 78 & 72 \\
Memeriksa Catatan & 73 & 69 \\
Mengatur Lingkungan & 94 & 88 \\
\multicolumn{1}{c}{ Rata-rata } & $\mathbf{8 1 \%}$ & $\mathbf{7 7 \%}$
\end{tabular}

Table is used with permission (CRochmawati, Livia Dinda. 2021. Persentase setiap aspek self regulated learning.

Berdasarkan Tabel 4 di atas, dapat diketahui bahwa setiap aspek self-regulated learning pada kelas eksperimen memiliki rata-rata yang lebih unggul dibandingkan dengan kelas kontrol. Sehingga dapat disimpulkan bahwa penggunaan media pembelajaran berbasis android studio pada mata pelajaran Korespondensi kelas X OTKP SMK Negeri 1 Turen Kabupaten Malang dikatakan efektif digunakan dalam proses pembelajaran, karena media pembelajaran yang dibuat signifikan dalam meningkatkan self-regulated learning peserta didik.

Peningkatan kemandirian belajar peserta didik yang signifikan pada penelitian ini disebabkan karena penggunaan media pembelajaran berbasis Android Studio yang memanfaatkan teknologi era milenial. Hasil penelitian ini sejalan dengan hasil penelitian yang dilakukan oleh (Putra and Nugroho, 2016) yang dalam penelitiannya menjelaskan bahwa pesatnya perkembangan teknologi bisa menjadi tantangan dan peluang khususnya untuk dunia pendidikan. Pada era milenial ini juga banyak peserta didik yang disibukkan dengan teknologi yang memudahkan dalam segala hal. Sehingga dengan adanya perkembangan media pembelajaran ini dapat memungkinkan peserta didik untuk mendapat kemudahan atas akses mereka dalam memperoleh materi-materi pembelajaran (Adi and Fathoni, 2019).

Adapun isi dari media pembelajaran berbasis Android Studio yang dikembangkan oleh peneliti ini adalah (1) Petunjuk, yang berisi tentang penjelasan penggunaan dan icon-icon yang terdapat dalam media pembelajaran; (2) Cakupan Kompetensi, yang berisi kompetensi dasar yang harus dicapai oleh peserta didik; (3) Tujuan, yang berisi tentang tujuan pembelajaran yang akan dicapai oleh peserta didik; (4) Materi, yang berisi tentang ringkasan materi yang sudah sesuai dengan KD yang disajikan dan dikemas dengan menarik; (5) Latihan Soal, yang berisi tentang latihan soal yang berkaitan dengan materi pada media pembelajaran; (6) Video, yang berisi tentang video yang berkaitan dengan materi pembelajaran pada media ini; (7) Fitur Gmail, yang berisi tentang tempat dimana peserta didik dapat mengunggah tugas melalui $e$ - 
mail yang ada pada media pembelajaran ini; (8) Profil, yang berisi tentang data diri singkat peneliti; dan (9) Pustaka, yang berisi tentang daftar rujukan pembuatan materi.

Isi dari media pembelajaran berbasis Android Studio yang beragam tersebut disajikan dan dikemas dengan menarik yang disertai dengan tampilan teks, gambar, dan video untuk menyesuaikan media pembelajaran yang dibutuhkan oleh peserta didik dan guru. Sehingga dengan adanya pengembangan media pembelajaran tersebut, dapat memudahkan generasi muda dalam melakukan tugas belajar mengajar (Shuib dkk, 2015).

\section{Simpulan}

Hasil akhir pada penelitian dan pengembangan ini berupa sebuah produk media pembelajaran berbasis Android Studio yang akan digunakan untuk meningkatkan hasil belajar dan kemandirian belajar peserta didik pada mata pelajaran Korespondensi KD 3.8 dan KD 3.9 kelas X di SMK Negeri 1 Turen Kabupaten Malang. Media pembelajaran ini dijalankan melalui ponsel berbasis Android yang sebelumnya harus melalui proses pengunduhan aplikasi melalui link yang dikirimkan. Untuk mempermudah penggunaan media pembelajaran ini, peneliti juga menyediakan halaman petunjuk penggunaan di dalamnya.

Hasil uji kelayakan media pembelajaran menunjukkan bahwa media yang dikembangkan oleh peneliti sangat valid dan sangat layak untuk digunakan sebagai media pembelajaran dalam kegiatan belajar mengajar. Kelayakan dan validitas produk yang dikembangkan dapat dibuktikan dari hasil validasi ahli materi, ahli media, dan pengguna uji coba kelompok kecil. Pengukuran tersebut dilakukan dengan menggunakan data kuantitatif dan data kualitatif.

Media pembelajaran yang dikembangkan oleh peneliti ini masih memiliki beberapa kelemahan, di antaranya adalah produk ini dibuat khusus untuk materi pada KD 3.8 dan KD 3.9. pengembangan produk selanjutnya diharapkan mampu memperluas jangkauan materi pembelajaran. Selain itu, media pembelajaran yang dikembangkan masih belum dapat digunakan pada ponsel berbasis iOS.

\section{Daftar Rujukan}

Adi, S., Fathoni, A.F., (2019). Development of Learning Model Based on Blended Learning in Sports School, in: Proceedings of the 5th International Conference on Physical Education, Sport, and Health (ACPES 2019), Atlantis Press, Semarang, Indonesia. https://doi.org/10.2991/acpes-19.2019.2

Ana, A., Achdiani, Y., (2015). Penerapan Self Regulated Learning Berbasis Internet Untuk Meningkatkan Kemandirian Belajar Mahasiswa Innov. Vocat. Technol. Educ. 11 https://doi.org/10.17509/invotec.v11i1.4835

Arsyad, A., (2003). Media Pembelajaran, 1st ed. PT. Raja Grafindo Persada, Jakarta.

Astra, I.M., Nasbey, H., Nugraha, A., (2015). Development of an Android Application in the Form of A Simulation Lab As Learning Media for Senior High School Students. EURASIA J. Math. Sci. Technol. Educ. 11. https://doi.org/10.12973/eurasia.2015.1376a

Bartholomew, S.R., Reeve, E., Veon, R., Goodridge, W., Lee, V., Nadelson, L., (2017). Relationships Between Access to Mobile Devices,Student Self-Directed Learning, and Achievement. J. Technol. Educ. 29. https://doi.org/10.21061/jte.v29i1.a.1

Firly, N., (2018). Create Your Own Android Application: Panduan Lengkap Membuat Apliksi Android. PT Elex Media Komputindo, Jakarta.

Kularbphettong, K., Putglan, R., Tachpetpaiboon, N., Tongsiri, C., Roonrakwit, P., (2015). Developing of mLearning for Discrete Mathematics Based on Android Platform. Procedia - Soc. Behav. Sci. 197, 793796. https://doi.org/10.1016/j.sbspro.2015.07.184 
Kusumadewi, W.A.P., (2016). Pengembangan Media Pembelajaran Berbasis Android Pada Mata Pelajaran Pemograman Dasar Di Kelas X Di SMK Negeri 3 Surabaya IT-Edu: Jurnal Information Technology and Education, 1(01).

Liliarti, N., Kuswanto, Heru, (2018). Improving the Competence of Diagrammatic and Argumentative Representation in Physics through Android-based Mobile Learning Application. Int. J. Instr. 11, 106122. https://doi.org/10.12973/iji.2018.1138a

Lubis, I.R., Ikhsan, J., (2015). Pengembangan Media Pembelajaran Kimia Berbasis Android Untuk Meningkatkan Motivasi Belajar Dan Prestasi Kognitif Peserta Didik SMA. J. Inov. Pendidik. IPA 1, 191. https://doi.org/10.21831/jipi.v1i2.7504

Mukti, I.N.C., Nurcahyo, H., (2017). Pengembangan media pembelajaran biologi berbantuan komputer untuk meningkatkan hasil belajar peserta didik. J. Inov. Pendidik. IPA 3, 137. https://doi.org/10.21831/jipi.v3i2.7644

Nurhayati, eti, (2011). Psikologi Pendidikan Inovatif, 1st ed. Pustaka Belajar, Yogyakarta.

Putra, D.R., Nugroho, M.A., (2016). Pengembangan Game Edukatif Berbasis Android Sebagai Media Pembelajaran Akuntansi Pada Materi Jurnal Penyesuaian Perusahaan Jasa. J. Pendidik. Akunt. Indones. 14. https://doi.org/10.21831/jpai.vl4il.11364

Setyosari, P., Sihkabunden, (2005). Media Pembelajaran. Elang Mas.

Shuib, L., Shamshirband, S., Ismail, M.H., (2015). A review of mobile pervasive learning: Applications and issues. Comput. Hum. Behav. 46, 239-244. https://doi.org/10.1016/j.chb.2015.01.002

Taufiq, M., Amalia, A.V., Leviana, A., (2016). Design Science Mobile Learning of Eclipse Phenomena with Conversation Insight Andoid-Based APP Inventor 2 Jurnal Pendidikan IPA Indonesia, 5(2), 291-298. https://doi.org/10.15294/jpii.v5i2.7375

Wahyuni, S., Djukri, D., (2016). Pengembangan Media Pembelajaran Berbatuan Komputer dan Kefektifannya Terhadap Kemandirian Belajar dan Penugasan Konsep Bryophyte. J. Inov. Teknol. Pendidik. 3, 79. https://doi.org/10.21831/tp.v3i1.8262 